\title{
Violent Upheavals in Kenya: A Literary Historiographical Analysis of Kinyanjui Kombani's The Last Villains of Molo.
}

\author{
JULIUS KIPKORIR A. CHEPKWONY \\ Department of Literature, Linguistics and Communication, School of Arts and Social Sciences, University Of \\ Kabianga, Kenya
}

\begin{abstract}
This paper is premised on a critical paper of Kinyanjui Kombani's The Last Villains of Molo (2012) as fictionalized account of Kenya's human conflict that has its genesis in the fight for political supremacy. Human conflict is often an ingredient of any literary text. The Last Villains of Molo is, in this paper, examined as repository of the political conflicts that end in the battle field. The primary text is augmented by relevant secondary materials. Data was extracted through qualitative research methodology that was library based. Close reading was done and extracted data was exposed to analytical research design. The paper focused on the intersection of history and fiction in the revelation of politically instigated wars. The paper relied on New Historicism theoretical framework. The theory, as propagated by Greenblatt, Montrose and Butler among others, examines literary texts as embedded in culture and as portraits of socio-economic realities of a society. It elevates history as a sub-text that can be fictionalized. The boundary between fact and fiction, history and fiction dissolves and are merged as manifestation of happenings that mirror the on-goings in society. This paper examines how the writer approximate history revealing the extent to which political profligacy cause untold misery and suffering on the populace. Through purposive sampling, Kombani's The Last Villains of Molo

(2012) was selected as the core text since history of ethnicity bulks in it. The paper shows that history and literature have a symbiotic interconnectedness. The text epitomizes ethnicisation, balkanization and repression as tropes of the troubled political history of Kenya.
\end{abstract}

Key words: New Historicism, political conflicts, ethnicisation, balkanization

\subsection{Overview}

\section{INTRODUCTION}

The section explores the relationship between the so called canonical and popular literary texts. It creates ground for the confluence between canonical and popular fiction as history.

\subsection{Background Information}

Literature is a social production of the socio-historical and political realities of the day. Kenya's historical transformation has been recreated in both historical and literary works to a varying degree. Since a writer does not write in a vacuum, he recreates a fictional world from a physical one. The physical world is made to live in the fictive world. Historical and literary worlds in effect intertwine. Walsh (2007) expounds on this relationship. He asserts that fiction has a second order relation to the real world through "mimetic logic of fictional representation; representing events that people assimilate through non-fictional modes of narrative understanding" [1]. Fiction and history relate in the presentation of social realities and happenings. Aristotle (1994) in his Poetics posits that "art imitates reality and that the universal can be found in the concrete." [2]Literature connects with the real world through artistic (re)presentation of social realities. This section provides background information on literature and historical discourses and the confluences between canonical and popular texts.

\subsubsection{The Confluences between Canonical and Popular Fiction}

Kenya has undergone important historical processes in its transformation since independence in 1963. The historical transformation processes have been captured and represented by some literary texts. These literary texts have been highly regarded while those that have not fictionalized history have been marginalized by the literati. Representation of historical and social cultural processes has been used to brand literary texts in a dialectic manner. History and literature relate in one way or another. Both deal with similar issues because they are constructed from the same society. Hutcheon (1999) strengthens this view when she postulates that the separation of the literary and the historical is but only artificial with both history and fiction having definitions and interrelations which are historically determined. Both share content and form. Discourses emanate from socio-cultural and political interactions within a society. Thiong'o (1981) puts it thus; 
Literature results from the conscious acts of men in society. At the level of the individual artist, the very act of writing implies a social relationship: one is writing about somebody. At the collective level, literature as a product of men's intellectual and imaginative activity embodies, in words and images, the tensions, conflicts, contradictions at the heart of a community's being and process of becoming. It is a reflection on the aesthetic and imaginative planes of a community's wrestling with its total environment to produce the basic means of life, food, clothing, shelter and in the process creating and recreating itself in history... [3]Hutcheon (1999) further contends that literature "works to situate itself within a historical discourse" [4]. In so doing, it does not surrender its autonomy as fiction. This reveals the close interaction and relationship between literature and history based on representation and implication. History, as a narration, chooses what to and what not to foreground. Similarly, literary texts can also foreground some historical transformational processes. Literature picks on what to include or exclude, have or not to have from historical happenings that are subjects of myriad interpretations. This is largely due to the fact that both history and literature are human constructs of the mind. Literature picks on circulating socio-historical discourses and recasts them. Chinua Achebe in Things Fall Apart (1958) recreates historical representation of the destruction that African culture undergoes in the hands of the imperialists. Okonkwo is an embodiment of the African culture that soon gives way to the Western culture. Things Fall Apart is a portrait of effects of colonialism and Christianity on African culture which is a historical reality.

Literature picks on what is in the immediate socio-political environment and re-articulates them in an aesthetic manner. Thiong'o (1972) avers that an African writer can help in articulating the feelings behind any struggles; be it oppression or exploitation. Popular fiction writers write from a given historical environment. Some literary theories like Marxism, Historicism and New Historicism focus on historical transformation. Marxist literary theory, according to Tyson (2006), looks at the socio- economic and political events that have been shaped by historical causes. Selden, Widdowson and Brooker (2005) strengthen this further by positing that "all ideological systems are products of real social and economic existence" [5]. Often, it is the material interests of the dominant social class that determines how people view human existence. Izevbaye in Durosimi (1982) contends that commitment implies literature should not merely exist in a vacuum. The writer should become involved in a kind of ideological dialogue with his society. This ideological dialogue is an interrogation of historical issues of the time. A confluence between history and literature thus exists.

Literature has a historical base. This advances the proposition that literary works are not the products of a single consciousness but many social and cultural forces that coalesce in representation of society. Ngugi (1981) further acknowledges this when he opines;

Literature is more than just a reflection on social reality. It is in itself part of man's self-realization as a result of his wrestling with nature. It is if you like, a symbol of man's creativity, of man's historical process of being and becoming... It does shape our attitudes to life, to the daily struggles within a community and the daily struggle within our individual souls and selves [6].

As such, literary works that capture the same historical process or transformation are highly regarded and seen as serious committed works by some critics and scholars. Such works become the dominant works of literature and are foregrounded as mainstream or canonical. Those that do not foreground important historical processes are marginalized. Popular fiction has been looked down upon as low brow with nothing serious to offer (Wanjala, 1980; Killam, 1984) and as an unworthy subject of serious academic paper (Birgit, 2008). The dichotomy of literary works comes into play. The literary texts that do not capture the important historical discourses or processes, like popular fiction, are viewed with condescension.

Popular fiction has been viewed as not being serious enough not only in the thematic concerns but also in not capturing the post-independent mood, euphoria and in not inculcating a sense of patriotism. Bardolph in Killam (1984) admits that popular literature is 'provocative, irreverent, and bawdy and there are no moral lessons from the "no-good hero" who is the main character [7]. This view is amplified by Calder, in Killam (1984) when she rubbishes popular fiction 'as having no real aim beyond entertainment and consequently, of no literary value'

[8].We can ably assert that works of minor writers have not received due attention since they have moved away from traditional themes of freedom struggle, land, exploitation and colonialism to contemporary subjects like hijacking, kidnapping, urbanization and school life. This view is supported by Ogembo (1995). In mind, he has popular literary writers the likes of Charles Mangua, John Kiriamiti, David G. Maillu and Sam Kahiga among others. While this is true, there are also some popular prose writers that have explored the 'socalled' traditional themes by recasting national discourses. Kinyanjui Kombani is representative of popular genre writers who amplify Kenya's historical reality through representation of historical transformation of Kenya's important moment in history: re-introduction of pluralistic politics and its ramification in society. Kenya, in this light, is seen as a 'site' or 'text' of historical space where the confluence between historical and 
artistic creation coalesce. Popular fiction, as a form of literature, fictionalizes the complex historical process of a society. How

Kombani's The Last Villains of Molo recreate Kenya's historical process was the subject of the paper.

White (1978) concurs with Casanova (1972) that both historical and literary discourses are inter-twined. Both exist as discursive constructs. At times, it is the historical discourses that have become a subject of literary scrutiny through artistic (re)presentations. Popular fiction as one form of literature has a close correlation with history. History becomes a meeting point connecting popular and canonical literary texts. Thiong'o (1981) observes that: "A writer is trying to persuade us, to make us view not only a certain kind of reality, but also from a certain angle of vision" [9]. It is for the reader to examine and interrogate this reality by engaging closely with the text. Tyson (2006) posits that meaning results from a close engagement with the text: meaning is not a stable element residing in the text for us to uncover or passively consume. Thus, meaning is created by the reader in the act of reading or more precisely, meaning is created by the play of language through the vehicle of the reader. In the paper, selected popular literary text was placed within the continuum of Kenya's historical trend of the1990s in Kenya. Important political discourses then were explicated. The historical representation as depicted in the selected text was examined and analyzed in details under New Historicism theoretical framework. They were examined under the premise that a close connection between literature and the historical context exist. A literary text that is realistic should actually reveal or approximate history. Historical sources, like those of literature, are man-made texts and therefore are subjective too. To thus dichotomize literature on the basis of absence or presence of history is contestable. The focal point is history or rather historical processes. At times, it is the historical discourses that have become a subject of literary scrutiny through artistic (re)presentations. Consequently, the paper analyzed dominant discourses prevalent in selected popular fiction that reconstruct historical happenings with a view to show that popular literature is also repository of history.

New Historicism strengthens the link between literature and history. According to Tyson (2006) history cannot claim to be objective and therefore it cannot be "understood in isolation from the web of meanings in which it is represented" [10]. He argues that there are two ways of understanding human society; through papering its literature or its history. History is examined as actualizing society in its depiction. Selected popular literary text is depository of the country's historical processes as they reconstruct political ideologies of the time. Literary texts are seen as a repository of "truths." Truths consciously refer to the multiplicity of meanings underlying the texts.

\subsection{Nature of the Problem}

Popular fiction has not been seriously theorized and has been regarded as less serious and unworthy subject by both the academia and the literati as postulated by Fabian (2007), Newell (2002), Shaeda (2009) and Gelder (2004). Fictionalization of history: socio-cultural \& political processes have often been used to categorize texts in a dialectic manner. History depicts the changes society has undergone. Such significant occurrences are often recreated by literary artists in different ways. A symbiotic relationship exists between literature and history. The relationship is based on the similarity of issues they are dealing with. The two mirror representations of the socio-economic and political experiences and realities of a community. A close connection between marginalized texts and canonical fiction exists in the presentation of historical transformations. Dichotomizing literature on the basis of socio-historical transformation is untenable. Historical and socio-cultural processes have often been used to categorize texts in a dialectic manner.

It explored the negotiation of the complex interplay of history and popular fiction in Kenya's multiparty era.

\subsection{Purpose}

The paper explicated historical discourses that capture Kenya's transformation processes and which provided insights into the social reality reconstructed in the so called popular fiction. In so doing these texts are appreciated as fictional reconstructions of history, in the same way that the mainstream canonical texts are appreciated. Fiction writers often attempt to historicize the country's socio-cultural and political transformation through interweaving history and fiction. The Last Villains of Molo invokes the violent experiences Kenya went through in the run-up to multi-party elections; worst of it all was the post election violence of $2007-2008$.

Papering The Last Villains of Molo invokes the violent past which individuals must learn from in order to create a harmonious environment for posterity. The novel does not merely depict the intersection of fiction and history but questions the hegemonic power control over the masses that hitherto is repressed in official mainstream narrative within the larger corpus of history.

\subsection{Contribution}

The reason for embarking on the paper was to bridge the divide between canonical fiction and popular fiction in terms of content and form. The paper sought to redress and reverse some scholar's view that popular fiction is an inconsequential genre which does not merit any serious consideration. The paper exposed a corpus 
of historical discourses interrogated by selected popular fiction: governance, ethnicity, power domination and polarization. It provides insights that can develop understanding and appreciation of popular fiction.

The research fits in the broader context of academic inquiry into the discourses of governance, politics and ethnicity from repressed histories of the Nation-state. It is hoped that the findings of the paper will initiate other scholars and critics to examine popular fiction closely and appreciate it as art. This will promote the development of and gain attention for the histories of marginalized fiction. It is also hoped that the conclusions of this research paper will make a significant impact and contribution on the place of popular fiction in Kenya. The paper examines one way in which popular literature can gain appreciation: papering historical processes portrayed in literary works. The rationale of the paper is to place popular fiction within the platform of literary circles. The characters depicted though fictitious epitomize the face of Kenya. Their stories are representative of Kenya's stories: violence, retribution, disenchantment and bitterness that may not be addressed in official history because of hegemonic control over the historical discourses in the country.

\subsection{Scope and Limitation}

The physical scope of this paper is Kombani's The Last Villains of Molo. The subject matter was limited to excavating the portrayal of Kenya's quest for plutocracy. Our interest lay in the important connections and interaction between historical context and fictional representation. The paper was bound by New Historicism. Popular literary works are bound up with other discourses in language system: making them part of historical representation.

\subsection{Materials and Method}

In order to attain the set objectives, qualitative research design that is library based was employed. Analytical research design was used. Through close reading, the paper undertook an in depth analysis of Kombani's The Last Villains of Molo, in the context of relevant tenets of New Historicism. Textual analysis was done exclusively on selected primary text in order to explicate relevant materials required on aspects of ethnic violence. Textual analysis also excavated relevant discourses and analyzed the extent to which selected popular fiction writer depicts the symbiotic interconnectedness between literature and history. Non-fictional texts were also read in order to correlate context with selected literary text.

\subsection{Background to Kombani's The Last Villains of Molo [11]}

\section{RESULT AND DISCUSSION}

The Last villains of Molo was written in 2004 but it was not until 2008 when it was launched. This coincided with the post-election violence in Kenya. The setting is in Kenya majorly in two locations. The rural and themetropolitan are juxtaposed in a parallel to allow the plot to cohere. The story opens in Ndoinet Forest, Molo (rural Kenya) in 1992. Thereafter, it shifts to Nairobi - the city, 2001.The story moves on in this manner allowing the reader to connect the temporal and the spatial. The prologue opens with a suggestive referent to concealment of moral responsibility. The girl cowers in her hiding place "her heart thundered in her chest" (v). The writer further describes her, "from her hiding place under the bed..." (v) typically suggesting oppressive status or intense fear as a result of the happenings. This propels us into human conflict as a result of misuse of power and ethnicity which does not assuage moral integrity. The rural Molo and its environs expose deep seated hostility between two predominant communities that strongly lay claim to land. Human conflict ensues as a result. This, coupled with political avarice, opportunism and intolerance makes the rural communities to clash. The story begins in the prologue that captures the attention of the reader.The literary text details senseless and wanton destruction of both property and human lives as a result of political instigation. It tracks the journey of five young men who move to the city, Nairobi from the rural Kenya. While in the rural area, their destinies intersect when they are thrust into ethnic bigotry. They fight for their communities in what is believed to be politically-instigated violence. They meet in worse circumstances during the fight from opposing sides. They are traumatized by the war they are thrust into. They realize, albeit lately, that peace and harmony must prevail beyond the tribal enclaves that the politicians have created. They flee the wrath of their ethnic communities for consorting with the 'enemy' and move on to Nairobi. They 'melt' into Ng'ando slums to seek solace and forget about their gory past. They camouflage their names while in the city in order to feel 'safe' as their community members are intent on liquidating them. To survive, they become amoral.

Gambling, larceny and such like activities is what they do to stay alive. The agony they undergo through rekindles in them a spirit that nurtures strength, amity and love.

\subsubsection{Introduction}

Literature and history relate extensively. History, according to Patrick Brady (1993) is a "representative of the past, a real past, a belief or set of beliefs about that past, claims to report the truth about the real past" [12] 
Consequently, history is a reconstruction of the past based on social happenings. The relationship between history and literature based on the interconnectedness constitutes the historical novel. Integrating historical issues into fiction manifests the notion that the two are symmetrically intertwined. LeBihan (96) amplifies this view that literature and history go together in a non-essential relation: "literature can be discussed without taking into account, and this history is therefore seen as something other than literature which can be used on relevant occasion" [13]. This demonstrates the interconnectedness of both disciplines since they operate on the same plane. Both are human-made constructs as averred by LeBihan which are ordered and shaped into narratives. These narratives can foreground or suppress some socio-political issues. Thus, literature, like history, chooses what to include or exclude. Popular fiction as one form of literature has a close correlation with history. History becomes a meeting point connecting both popular and canonical literary texts. Both are at variance in the manner of representation. While historical discourse, according to LeBihan hooks on to the world according to its referentiality, literary discourse manipulates language through the use of dominant tropes like symbols, metaphors and other images. New Historicism strengthens the link between literature and history. According to Tyson (2006) history cannot claim to be objective and therefore it cannot be understood in isolation from the web of meanings in which it is represented. He argues that there are two ways of understanding human society; through papering its literature or its history. History is examined as actualizing society in its depiction. Selected popular literary text is depository of the country's historical processes as they reconstruct political ideologies of the time. A literary text is seen as a repository of "truths." Truths consciously refer to the multiplicity of meanings underlying the texts. History, as an artifact, forms a background against which a text reflects. As a product of the socio-historical environment, Kombani's The Last Villains of Molo reconstructs Kenya's historical process. The popular belief that history is more factual while literature is subjective is but fallacious. History has a symbiotic relationship with literature. White, (2005) postulates that historical writings are a reflection of literary writings and vice versa. This is because both share the narrative of meaning which is embedded in the language used. Kinyanjui Kombani's engagement with history is conspicuous. His selected text reflects historical dialectic of transition from single party to multi-party politics in Kenya. This transition witnessed ethnic violence that saw people killed. It became a painful reminder that inept leadership courts death.

The Last Villains of Molo fictionalizes the historical events in Kenya in the lead up to the first multiparty elections in 1992. The author renders the narrative strand live by using fictive characters that can be seen as ordinary. He exploits omniscient narrator to foreground the narrative of pain, anguish and retribution. The following are the literary discourses that intertwine with historical ones.

\subsubsection{Ethnic bigotry}

Kombani explores the explosion of simmering ethnic bigotry that mediates between the past and the present as he tries to give hope to posterity. The Last Villains of Molo creates a parallel connection with the historical happenings within the same historical epoch by weaving a complex plot of the attacker and the attacked, the hunter and the hunted, the oppressor and the oppressed connecting the pair in a bond of the central metaphor of "villainy." This sets in motion complex encounter of two ethnic groups that have co-existed peacefully.

Dimensions of enemies; imaginary or real, political or apolitical, mingle with bitterness, pain, suffering and agony to epitomize the writers' need to knead a coherent whole and reveal the havoc that incompetent leadership brings. The selected novel becomes more fascinating when suspense and intrigue are intertwined in the narration to reveal the vicious cycle of events. One can predict with some precision that in any electioneering period in Kenya there must be politically motivated violence. Such has been captured in books in the lead-up to 1992, 1997 and 2007 elections. Kombani's selected popular novel reveals major aspects of New Historicism. History as the context and fiction as the text are both connected in the disclosure of events. The rural and the urban are merged to come up with a gripping plot that indict the abuse of ethnicity and political patronage to gain political mileage and hold on to power. Selected literary text was read as an indictment of the inability of those in authority to provide justice, protection and democratic space to the citizenry during and immediately after general elections in Kenya. The ruling hegemony stirs ethnicity in an emotional encounter. The five principal characters, young as they are fall prey to ethnic bigotry being advanced by the ruling elite. They and their families face each other in the battle ground. More often than not ethnicity has had negative effects in most African countries. This is attributed to the notion that those who control power 'benefit' a lot. They get direct favors or other material benefits from the ruling hegemony: a reason which ethnicity is used to exclude others in politics. This creates devastating consequences. Barasa (1997) in his historical text, states that the re-introduction of multiparty politics in Kenya, has had consequences one of which is the eruption of ethnic flare-up. Ethnic intolerance results from mistrust and suspicion created by the powers that be. Kombani's The Last Villains of Molo is a historical documentation of the multiparty interface reality in Kenya in 1992. During this time, clashes rocked Rift Valley and specifically Nakuru region. Barasa (1997) augments this: 
It is a historical fact and current reality that most Kenyan districts are haunted by actual or potential ethnic conflicts. This is partly because of the fact that different communities continue to consciously or unconsciously rely on ethnicity to perpetuate their dominance and hegemony in an atmosphere characterized by scarce resources, fear and prejudice [14].

The ugly side of intolerance and mistrust is well captured in the prologue of Kombani's Three Days on the Cross. Young people are thrust into the front line of a battle they do not fully concretize. They do not even know the genesis of ethnic acrimony. The young girl in the prologue has never witnessed the arson and killings that go on during the upheaval. The experience is traumatizing: destruction of property and human life. It is her father's murder in cold blood that forms her passion for revenge. "She looked from her fallen father to the intruders, her heart quickly filling with hatred" (Kombani: vi). This hatred defines her future and her relation with other people and society. Neighbors have co-existed in harmony before. Children and young people have formed camaraderie which transcends ethnic and religious lines. The predominant communities that have existed in the former Rift Valley in Kenya are the Kikuyu and the Kalenjin. Kombani traces the entry of the Kikuyu ethnic group to Rift Valley in the early 1970s. Both ethnic groups accepted each other and co-existed in peace and harmony. This is actually witnessed in the text when Mwalimu Kipruto, a Kalenjin, goes to warn Waweru, a Kikuyu, of the impending danger of escalation of violence. Both communities consider the area they are occupying as their ancestral land. Not until when multi-party politics take the centre stage is when ethnic bigotry rears its ugly head.

Negative ethnicity becomes a space for contestation in the land politics. Land dispossession is a means to compel allegiance to the hegemony. But this does not augur well with some members of one ethnicity. That is why when told to vacate because of imminent violence, Waweru answers back, "I do not see why I should leave my ancestral land" (Kombani, 55).

The narrative of ethnicisation is weaved with utter abandon regardless of the effects to the populace. Ethnicity and nationalism, according to politicians, become two parallels that diverge instead of converging. Ethnicity provides them with platforms for political mobilization to achieve their ambitions and serve their insatiable greed for power. These power hungry leaders whose interest is to cling on to power are keen to use any means, devious or otherwise to retain the status quo. Politicians care less if people are killed leave alone being dispossessed. The government is thus shown as insensitive, callous and indifferent to the suffering of the citizens. A government that only values her people in terms of votes they deliver shows how it is only interested in perpetuating itself in power. Kenya Human Rights Commission Report (2011) accuses the government of involvement in instigating and promoting violence during the inter-tribal conflict between1991-1998. This connects history with fictional representation of events thereby bridging context and text.

The right of claim of ownership of land is a manifestation that intensifies ethnic rivalry fuelled by politics of exclusion. In Kombani's The Last Villains of Molo, Mzee Kipyegon, a Kalenjin, depicts a deep seated bigotry when he contemptuously looks down upon members of Kikuyu ethnic community. The Kikuyu-Kalenjin bigotry may stem from laying claim to ancestral land. The Kalenjin consider the Kikuyu as aliens that came to occupy what is not theirs by ancestral rights. Mzee Kipyegon abhors them and likens them to the proverbial camel that was allowed only one foot inside its mother's tent during a storm but with time had its whole body in "leaving the Kalenjin drenching in the rain" (Kombani, 41).Ethnic animosity is further stoked by the impending elections. Leaflets ordering "outsiders" (54) to vacate the area immediately are spread all over. This heightens the existing tensions between the two predominant communities and casts the two into conflict. The two are put in collision path thereby widening ethnic rift between the two communities. The Truth, Justice and Reconciliation Commission Report (2008) supports this view, from its own research findings that the government of the day supported the skirmishes to eject some groups of people in some political zones. Msindo (2007) avers that ethnic groups "do not exist primarily as political institutions to fight off opponents but pressure their cultural artifacts, their traditions...." [15].In the selected literary text, ethnicity is used to zone areas in terms of politics. The tribal index is one that causes relocation, dispossession and deaths. This is because it has been abused by the leadership. Ethnic bigotry becomes an index of selective exclusion from mainstream politics and governance.

\subsubsection{Violence}

Ethnicity breeds discord and violence. Violence is a tool often used by undemocratic governments to 'silence' those perceived as opponents. Politicians whip up ethnic emotions to create an atmosphere conducive for violence. As Murunga (2011) puts it, violence is a catastrophic consequence of impunity within the ruling class and the state; due to 'normalization of violence' in society and also as a consequence of weak institutions that have been repeatedly abused [16].The ruling class puts ethnicity to political expedient use with the hope of clinging on to power. As is captured by Kombani in his selected literary text, the government perverts justice by abetting violence that is perpetrated in order to gain political control. An election drawing close becomes a recipe to plant seeds of discord and animosity. Politicians appeal to the deep-seated suspicion that arouses 
treachery and eventual violence. Political mobilization as witnessed in Kombani's The Last Villains of Molo is done through what Murunga (2011) refers to as "ethnic prism" [17]. He further argues that the political class encourages their ethnic communities to turn to violence in order to build electoral blocks and to perpetuate their dominance and hegemony. Refugee Consortium of Kenya (Haki NGO Group) (2005) in its research corroborates the above. It acknowledges that violence is used as a tool to retain political monopoly in areas designated as "exclusive" to particular ethnic communities and political parties. Politics of division quite often creates room for violence. What even aggravates ethnic suspicion and conflict is the feeling that there has been an unfair distribution of resources since independence. This is mere suspicion by one ethnic group - who feel threatened by the 'new comers' as they have been made to believe. The business rivalry and underhand deals inflames the animosity. In Kombani's The Last Villains of Molo one community out-competes the other in business. A feeling of loathe develops to an extent that one individual, Mutai (from the Kalenjin community) verbalizes aloud "I hate Kikuyus" (Kombani, 38) to the consternation of his Kikuyu assistant, Karuri. Angelina Chebet, a Kalenjin, in similar predicament too, harbours feelings of bitterness especially when Molo District Hospital firewood and vegetable tenders are given to Macharia, her most trusted and loyal assistant. Ethnic rancor breeds contempt and bitterness that creates suspicion and conflict which escalate into war. As has been observed, the police are impotent in ending the violence. Kanyongolo (1998) agrees when he opines that violence has "a strong political dimension and is always heightened by the apparent unwillingness of the police to quell it with the same zeal with which they deal with other 'public disorder incidents'- particularly those related to activities by the anti-government protesters" [18].

This unwillingness is because they are not given requisite orders by their superiors. In his investigation of the 1991-1994 political violence in Kenya, Kanyongolo (1998) surmises that supporters of the ruling party, KANU, attacked members of the ethnic groups who were considered to support the opposition then. He goes on further to state that his investigation showed that high ranking government involvement was proven. This confirms what Kombani artistically recreates in his literary text. History and fiction merge as one text. This view is amplified by New Historicism. Murunga R (2011) agrees that leaders undermine nation building by sowing seeds of discord and pitting communities against each other in the struggle for political supremacy and the economic rewards that go with high office. Violence is a tool used to achieve, sustain and maintain power and win elections. Kombani in The Last Villains of Molo relives the violence that escalates as a result of political instigation. His description is raw, unnerving and haunting. Close neighbours engage in a combat. He describes in detail the heartlessness of the brutal orgy of violence; one person had a deep cut right across his stomach, and his shirt was soaking in fresh blood. Mzee Mbure ripped open the wounded man's bloodstained shirt apart and helped him push back the intestines into his bowels. The sight was painful to bear - the man's stomach had literally been torn open (Kombani, 65).

Akinyi, Kamau and George (2011) in their field research found out that the historically-bred tensions in Rift Valley have been battle grounds for open conflicts between two large communities. Ethnic mistrust has caused divisions which the ruling regime capitalizes on to balkanize regions. Ndung'u and Kombani reveal the historical violence that makes people lose lives. Those whose allegiance is with the opposition are regarded as 'outsiders' and must be 'uprooted' at all costs. Ndung'u in A Friend of the Court refers to them as 'madoadoa' meaning that they are people who, metaphorically are of different color. In a political sense, they are people who belong to the opposition.

Rape is used as a manifestation of intense ethnic violence. Not only does it devastate the victim but it also dehumanizes them. Kombani's The Last Villains of Molo is a portrait of this reality. Members of the Kikuyu community gang rape Kirui's wife in the full glare of her children and husband. The husband could even see the sardonic grins of his attackers as they humiliate him. An overwhelming sense of vulnerability paralyses him. The psychological trauma is too deep. The indignation dehumanizes him and he is reduced to a village madman. Ethnic animosity creates sworn enemies. The divide attests to the fact that conflict makes individuals retreat to their ethnic cocoons to 'protect their own.' This causes humiliation, shame and feeling of vulnerability. Rape is part of torture, a permanent mutilation of an individual's life. Rape has been used as a weapon of war. It was used in the World War II by the Allied and Axis armies who committed it as a means of terrorizing enemy civilians and demoralizing and indignifying enemy troops. In Encyclopaedia Britannica (2010), rape is revealed as a tool to victimize and reduce the victims into objects. "Objectification" is rendered as sexual exploitation. It is the worst form of ignominy that completely makes the victim less human. It is actually violence against humanity. Violence is exacerbated further by counter-attacks. Where the government is ineffectual, people become vindictive.

Communities arm themselves for retaliatory attacks. The Government's unwillingness to protect the rights of all citizens is seen through the laxity of the security officers. Violence is often fuelled by greedy politicians and weak governance. Murunga (2011) acknowledges this fact when he postulates that politicians escalate violence to escape responsibility and muster more power. Politicians are seen to galvanize power through unorthodox means. 


\subsection{Summary, Conclusions and Recommendations \\ 2.2.1 Introduction}

This last section summarizes the findings for the paper and their implications for the general historiographical criticism of selected popular fiction. It specifically outlines in detail conclusions of the paper and especially those that are related to the set topic that the paper sets to answer. In addition suggestions for further research have been made. Kombani's The Last Villains of Molo is an attestation of how the ruling hegemony is a captive of ethnicity. The paper has ably revealed how historical ethno-violence is fictionalized in literary text. The country has vivid illustrations of the violence. A case in point is the 2007-2008 violence where over one thousand two hundred people were killed and over half a million people were displaced. In his portrait of history, Kombani has significantly let conflict and violence to be the dominant theme. There is sin and there is no punishment. There is death and there is no atonement. People kill others yet there is no redemption. People are uprooted from their ancestral land, the security agents do nothing. There is displacement and dislocation yet the security agents only watch. Women are raped, nothing is done again. In this gloomy, hopeless situation, the writer is suggesting that living and co-existing in harmony reside in every individual member of a community. Solutions to conflict must emanate from the people. In the end, people must learn to co-exist with others. Selected popular writer thus invite readers to read critically and consume Kenya's troubled history in the 1990s during the clamour for democratic space in Kenya. The writer deconstructs and destabilizes the narrative from the hegemony and rearticulates that of the victim, the affected citizenry. The paper has examined selected popular literary works by a Kenyan writer, Kinyanjui Kombani.

\subsubsection{Summary}

The findings revealed that literature in one way or another mirrors the happenings in society. Literature and history not only relate extensively but they go hand in hand. Literature and society relate in a way that fiction reflects on society and society too is reflected in the fiction of the time. The changing conditions of a society are often recreated in literature; whether popular or mainstream literature. The findings show that popular literature depicts these changing circumstances in society. The studied text reveals pain, anguish and suffering people underwent in the hands of exploitative comprador bourgeoisie. The 1990 literary epoch has revealed the important historical discourses reconstructed in literary fiction. Issues of importance include governance, politics and identity. Renowned writers capture these discourses in their literary texts. They include Oludhe Macgoye's Coming to Birth and Margaret A. Ogola's The River and the Source. Selected popular literary text also reconstructs the appropriation of similar historical discourses in a way as to show Kenya's historical process. Selected popular fiction recreated Kenya's historical transition from single party to multiparty. We argued that the introduction of plutocracy was not smooth. Violence that defined the country's stability rocked most areas. Some communities were forced out of their ancestral land in Molo.

The paper established that injustices meted on groups of people in the quest to scuttle the clamour for democratic space coupled with incarceration and intimidation become a historical scar in the country's archives of happenings. Selected text addresses the interconnectedness of history and literature. Historical discourse can beef or be supplemented by literary discourse as both emanate from society. Literary rendition of historical happenings qualifies to be authoritative. We were interested in examining how literary aesthetics and representation offers an alternative perspective to historical textuality. In particular we examined how popular fiction artistically recreates important historical events as Kenya underwent transformation with a view to showing that literary text classification is ambivalent. We have argued that socio-historical issues, which too can be viewed as textualities cannot be used to categorize literary texts. Society often undergoes changes and transforms itself throughout history. There is no culture that is static. Kenya's society has shown dynamism. In the 1990s a new quest for struggle; justice and democracy formed part of the prevailing historical struggle for plutocracy. This was necessitated by the highhandedness of the ruling hegemony. As such issues of governance and effects of suspicion and intolerance of ethnic groups come to the fore. The misconceptions that popular fiction does not recreate serious historical 'facts' or significant occurrence that reveals the country's transformation, is misplaced. Any work of literature often derives meaning from the interplay of socio-cultural, economic and political forces in society.

Even though literary events are not so much dependant on history for accuracy or significance, New Historicism, according to Rivkin and Ryan (2004), avers that "history is only available discourses that construct the past" [19]. It is not, we argue, some unmediated reality outside there nor is it some stable background which the literary text refers or reflects. It is seen as a literary text itself though of different genre. On their own, we have argued literary texts as representations of events would not stand alone. They actually need the backdrop of history to qualify them.

We have also argued in the paper how selected works approximate or portray history. The Last Villains of Molo encapsulates the ethno-violence that rocked the country in 1992 in the first multi-party epoch in Kenya. 
Selected literary text clearly recreates such historical happening. The text follows the account of relocation of five youths who 'melt' in Nairobi environs in order to forget the chilling mayhem that had occurred in the village and which is still etched in their minds.

The text replays Kenya's historical injustices to groups of people: where one community dispossesses the other yet all along they have co-existed amicably. We argue that history and literature cannot be divorced from one other and vice-versa. They complement each other in recreating happenings in society. None is seen as superior to the other in representation of events within a given time frame. Both are representations and according to Rivkin and Ryan (2004) none is closer to the truth of history. The paper has illuminated the notion that historical versions of events, like literature are recounted events.

The paper makes significant contribution to studies of Kenyan popular literature that have emerged over the last decade. This study, therefore, concurs with similar studies by Kurtz (1993), Ogude (2004), Kithendu (2000) and Ndlovu (2010). The multi-cultural and multi-ethnic composition of Kenyan society makes it complex to examine socio-historical issues in isolation. Literature becomes one of the most powerful tools to reveal and or represent histo-political conflicts. Another important observation is that literature - whether canonical or popular-responds to the emerging historical happenings. Such artistic works stand as a concrete instance of historical "fact." They represent a fictionalized mimetic version of historical 'reality' where language is used artistically to foreground particular issues.

Literary texts thus manifest themselves as representations of fictionalized recreation of historical happenings. This concurs with Jameson's (1981) perspective that all third world narratives are allegories of the nation. They paint the nation the way it is at a particular time. The paper has ably shown how literary artists recreate the narrative of the dispossessed, the marginalized victims that would have otherwise been repressed in Kenya. Findings show another version of official history of the multiparty politics.

\subsubsection{Conclusions}

The paper engaged with Kombani's The Last Villains of Molo, on the question of historiography in Kenya's context at a particular epoch. What was of importance was the resilience and optimism that the main characters exuded in the face of provocation and anguish. Literature and history relate extensively. As much as fiction is created, history too is re-constructed from a particular perspective. New Historicism contextualized the paper and brought together the literary text and the historical context. The paper was largely informed by the ideas of Greenblatt on history. The paper concurred with the concept that historical background shape literary productions of the time. A strong connection between literature and history depict the unique symbiosis in both. The two operate in different planes because their methodologies are at variance. The content of both is shown to be similar as the convergence is the society.

The paper demonstrated how the themes of governance, power and identity are appropriated in selected literary text. The politics of plutocracy positioned avaricious leaders to consciously exclude 'others' resulting in ethno-violence. The historical path of ensuing conflict is shown to have defined Kenya's transformational process. Historical happenings and fictional representation are inextricably connected. Popular literature, as has been established by the paper, is a vehicle through which historical process is portrayed. The paper concludes that historical and socio-cultural process which has been used to dichotomize literary texts is mere human construction.

A study of the selected popular fiction is a confirmation that history and literature is interwoven. Author of selected fiction make reference to real names of places; towns and villages to situate events which to a large extent mirror such places and events that happened within the time span given.

The paper has dissected the process of classification based on inclusivity of important historical happenings. Through the study of conflict and ethno-violence, a conclusion is reached that there exists a symbiotic relationship between history and popular literature in the same way it does in mainstream literature. Both literature and history supplement and complement each other for a deeper understanding of society. This echoes Rice and Waugh (1996: 229) views that "political and social needs shape literary reception" [20]. We found out that popular literary texts echo historical discourses that characterize a given literary epoch.

Reading popular literature informs and widens not only our understanding of literature itself but also of the society we re-construct. We rightly concur with Ndlovu (2010) who asserts that 'attention should be paid to the popular narratives that have been coming out of Kenya' [21] as they are manifestations of socio-cultural happenings in society.

\subsubsection{Recommendations}

It is worthwhile to note that selected literary text acknowledges that redemption is possible in any conflict. Communities need to embrace tolerance and trust in order to rewrite positive histories. Selected popular writer is concerned with socio-political and cultural issues. It is however, recommended that examination of 
other socio-religious issues that the writer recreate can be done. Each writer can be examined singularly to trace the philosophical disposition that runs in all their artistic works.

\subsubsection{Suggestions for Further Research}

The paper was limited to excavating Kenya's historiography from the point of view of selected popular fiction writer. In his novel, he deconstructed the narrative of the hegemony that only depicts history from the exploiter matrix. Perhaps, as a suggestion, the ideological and psychological perspective of the sadistic leaders can be looked at. The paper was also limited to examining singular novel from selected writer. We recommend that his other novels can be looked into in order to affirm his ideological approach or perspective to issues that act as a mirror to society. It is also suggested that the characters may be examined as a creation of the political actions of the hegemony.

\section{ACKNOWLEDGEMENTS}

I wish to appreciate the dedicated contribution of my supervisors, Dr. Solomon Waliaula, and Dr Peter Muindu. I would first thank most sincerely Dr. Solomon Waliaula of Maasai Mara University, Kenya. Without his initial professional guidance I would not have made it this far. His academic guidance and unwavering support kept me directed to my academic course. Above all, his encouragement lighted my path to realize that for any insurmountable work, there is always hope at the end. You made it possible for this work to be realized. I also do sincerely thank Dr. Peter Muindu for his readiness to show the academic path to be followed. His tireless effort and selfless guidance inspired me to work diligently. He labored tirelessly to give this work a sense of direction even beyond the normal times for duty. His readiness was shown by just a mere call. A big thank you.

I profoundly appreciate the Dean, School of Arts and Social Sciences, University of Kabianga, Kenya; Prof. Issa Mwamzandi for his encouragement when I had faltered and almost given up hope. Thanks Prof. I am indebted to our H.O.D Prof. Jack Ogembo for his support and encouragement. Anne Jose, thank you too for your assistance. I should also thank my family members for their understanding and appreciation. Above all, I praise and thank the Almighty for His sustenance, gift of life and promise. Greater things are ahead.

\section{REFERENCES}

[1] Richard Walsh. The Rhetoric of fictionality: narrative theory and the idea of fiction. (Columbus, Ohio State University Press, 2007) 13

[2] Aristotle. "Poetics." The Internet classics archive. 1994: Web. http://classics.mit.edu//Aristotle/poetics.html (accessed November 20th, 2014). 2

[3] Ngugi wa Thiong'o, Writers in politics. (London, Heinemann, 1981) 5-6

[4] Linda Hutcheon, "Literature meets history: counter - discoursive comix". 1999. (accessed August 18th, 2014, Web) 105

[5] Peter Selden, Widdowson and Ralman. A Readers guide to contemporary literary theory (Edinburgh: Pearson Longman, 2005) 94

[6] Ngugi wa Thiong'o, Writers in politics. (London: Heinemann, 1981). 6

[7] Bardolph, Jackline. "The Literature of Kenya." In The Writing of east and central africa, by Killam G (edi). (Nairobi: Heinemann,1984). 44

[8] Angus Calder, "Meja Mwangi's Novels." In The Writing of east and central africa by G. edi. Killam. (Nairobi: Heinemann, 1984) 178-179

[9] Ngugi wa Thiong'o, ibid, 6

[10] Tyson Lois, Critical theory today: a user friendly guide, 3rd Edition. (New York: Routledge, 2006). 186

[11] Kombani, Kinyanjui. The Last villains of molo. (Nairobi: Longhorn, 2012).

[12] Brady, Patrick. Memory and history as fiction; an archytypal approach to the historical novel. (Knoxville: New Paradigm, 1993). 17

[13] LeBihan, Keith Green and Jill. Critical theory and practice. (London: Routledge: 1996). 92

[14] Barasa, Nyu.kundi Kundu. "The Impact of past and potential ethnic conflicts on Kenya's stability." USAID Conflict resolution in greater horn of africa. (Nairobi: University of Nairobi: 1997. 1-50). 3

[15] Msindo, Enocent. "Ethnicity and nationalism in urban colonial Zimbabwe; (Bulawayo 1950-1963." Journal of African History, 2007: 267-290). 269

[16] Godwin Murunga, Spontaneous or premeditated? Discussion Paper in Nordic African Institute, (London: Lighting Source, UK Ltd: 2011). 9Godwin Murunga, ibid 9

[17] Kanyangolo, Edge. Article 19, Kenya post-election violence. (Nairobi: Human Rights Watch; December, 1998). 6

[18] Michael Ryan and J. Rivkin(Ed) Literary theory anthology (Blackwell; Oxford 2004). 506

[19] Philip Rice and P. Waugh (Ed)Modern literary theory; a reader $3^{\text {rd }}$ edition, (London: Arnold 1996). 229

[20] Isaac Ndlovu, An Examination of Prison, Criminality and Power in Selected Contemporary Kenyan and South African Narratives. $\quad$ Doctoral diss., (Stellenbosch: Stellenbosch University Press 2010). 240 